\title{
Macronutrient Intake and Inadequacies of Community-Dwelling Older Adults, a Systematic Review
}

\author{
Sovianne ter Borg ${ }^{a} \quad$ Sjors Verlaan ${ }^{a}$ Donja M. Mijnarends ${ }^{b}$ Jos M.G.A. Schols ${ }^{b, c}$ \\ Lisette C.P.G.M. de Groot ${ }^{d} \quad$ Yvette C. Luiking $^{a}$ \\ ${ }^{a}$ Nutricia Research, Nutricia Advanced Medical Nutrition, Utrecht, ${ }^{b}$ School CAPHRI, Department of Health Services \\ Research, Maastricht University, Maastricht, 'School CAPHRI, Department of Family Medicine, Maastricht University, \\ Maastricht, and ${ }^{\mathrm{d}}$ Wageningen University, Division of Human Nutrition, Wageningen, The Netherlands
}

\section{Key Words}

Macronutrient · Energy · Inadequacy · Intake ·

Community-dwelling older adult

\begin{abstract}
Background: Anorexia of ageing may predispose older adults to under-nutrition and protein energy malnutrition. Studies, however, report a large variation in nutrient inadequacies among community-dwelling older adults. Summary: This systematic review provides a comprehensive overview of the energy and macronutrient intakes and possible inadequacies in community-dwelling older adults. PubMed and EMBASE were screened up to December 2013; data from national nutrition surveys were added. Forty-six studies were included, following the PRISMA guideline. Key Messages: Mean daily energy intake was $8.9 \mathrm{MJ}$ in men and 7.3 $\mathrm{MJ}$ in women. Mean daily carbohydrate and protein intakes were 46 and $15 \mathrm{En} \%$ in men and 47 and $16 \mathrm{En} \%$ in women, respectively. Mean daily total fat, saturated fatty acid (SFA), mono-unsaturated fatty acid (MUFA) and poly-unsaturated fatty acid intakes were respectively 34, 13, 13 and 5-6 En\%. The carbohydrates and MUFA intakes are below the acceptable macronutrient distribution ranges (AMDR). Fat intake is relatively high, and SFA intake exceeds the upper-AMDR.
\end{abstract}

Based on the estimated average requirement (EAR) cutpoint method, $10-12 \%$ of older adults do not meet the EAR for protein. To interpret a possible energy imbalance additional information is needed on physical activity, energy expenditure and body weight changes. This systematic review indicates a suboptimal dietary macronutrient distribution and a large variation in nutrient intakes among communitydwelling older adults.

(c) 2015 The Author(s) Published by S. Karger AG, Basel

\section{Introduction}

An estimated $21 \%$ of community-dwelling older adults show symptoms of anorexia of ageing [1], which is loss of appetite and/or decrease in food intake. Multiple factors contribute to a decreased food and nutrient intake in older adults, including sensory changes, diseases, medication use and psychological factors such as depression [2-4].

Anorexia of ageing may predispose older adults to undernutrition and protein energy malnutrition $[5,6]$. Energy requirements decrease with age as a result of a decreased energy expenditure, physical activity and fat free mass [7]. The fall in food consumption and hence energy intake, however, is often greater than the decrease in energy re-

Sovianne ter Borg, MSc

Nutricia Research

Uppsalalaan 12, PO Box 80141

NL-3508 TC Utrecht (The Netherlands)

E-Mail sovianne.terborg@ nutricia.com 
quirement, resulting in weight loss. Reduction of energy intake may also result in decreased intake of other nutrients and thereby result in nutrient deficiencies. Nutrient requirements, however, do not necessarily decrease with age, and even tend to increase. An example is vitamin $\mathrm{D}$, for which older adults are identified as a risk group for deficiencies [8], and for which the recommended levels have recently been adapted for older individuals $[9,10]$. The need for protein might also increase because of age-related conditions such as loss of muscle mass [11]. For protein intake, the reference values for older adults are topic of continuous debate and a higher recommended level for older adults is argued by protein experts in the field $[12,13]$.

Besides adequate quantity of energy and nutrient intakes, the quality of the diet should also be considered. Diets with specific ratios of macronutrients (carbohydrate to fat) are associated with the risk of coronary heart disease and diabetes [14]. Adhering to the nutritional reference values (NRV) is important to reduce the chronic disease risk, while still maintaining adequate micronutrient and essential fatty acids intakes [14].

Both anorexia of ageing and weight loss are related to frailty [15] and disability [16]. Undesired weight loss is also known to be associated with increased risk of hip fractures [17] and institutionalisation [18] and may contribute to the loss of independence and subsequent survival [19]. Further insights into the nutrient intake and diet quality of older adults may contribute to improvement in healthy aging and overall quality of life. Hence, the objectives of this systematic review were to (1) describe the habitual dietary intakes of energy and macronutrients among community-dwelling older adults in Western countries and (2) compare their energy and macronutrient intakes with NRV.

\section{Method}

This systematic review follows the Preferred Reporting Items for Systematic reviews and Meta-Analyses (PRISMA) statement [20].

\section{Search Strategy and Study Selection}

The electronic databases PubMed (http://www.ncbi.nlm.nih. gov/pubmed/) (1950-December 31, 2013) and EMBASE (http:// www.embase.com/) (1993-December 31, 2013) were searched for studies. Search terms were limited to title and abstract and had no language restrictions. The following search terms were used: 'elderly', 'geriatric', 'older adults', 'older people', 'senior', 'older person', 'aging'; AND 'nutritional status', 'nutrient deficien*', 'nutrient intake', 'nutritional intake', 'food intake', 'dietary intake', 'dietary adequacy', 'nutrition assessment', 'diet records'; AND 'populationbased study', 'longitudinal study', 'epidemiologic study', 'cohort study', 'prospective study', 'cross-sectional study', 'populationbased design', 'longitudinal design', 'epidemiologic design', 'cohort design', 'prospective design', 'cross-sectional design'. Animal studies were excluded in the PubMed and EMBASE search. A reference check was performed to identify additional relevant studies. The full search string, as used for the PubMed search, is provided in online supplementary file S1 (for all online suppl. material, see www. karger.com/doi/10.1159/000435862). To make the study complete, national food consumption survey data from the European Nutrition and Health Report [21] were added. A recent European Food Safety Authority (EFSA) scientific opinion report was checked for additional national food consumption surveys [22].

The titles and abstracts were screened independently by 2 reviewers (S.t.B. and D.M.M. for the first search period, S.t.B. and Jaimie Hemsworth for the second search period) following predefined selection criteria: studies were eligible if they contained nutrient intake data (reporting both mean and standard deviation (SD)), did not include a nutritional intervention, mean age $\geq 65$, and had data originating from Western populations (Europe, North America, Australia, New Zealand).

Full-texts were retrieved and assessed (S.t.B. and Jaimie Hemsworth) based on the selection criteria stated above and the following additional criteria: community-dwelling older adults, non-energy and age-adjusted data and explicitly presented macronutrient intake data. Community-dwelling older adults were defined as those living at home, in private households, independently living, free living or non-institutionalised. In order to prevent the inclusion of duplicate data, author names, countries, sample size and nutrient data were compared. Studies with the highest sample size were included in case of duplicate reporting. For data analysis requirements, studies stating only the overall (men and women combined) nutrient intake data were excluded. Whenever there was a doubt about inclusion, a third reviewer (Y.C.L.) was consulted and inclusion was based on consensus.

\section{Data Extraction and Quality Assessment}

For each of the included studies, mean daily dietary energy, carbohydrate, protein, fat, saturated fatty acid (SFA), mono-unsaturated fatty acid (MUFA) and poly-unsaturated fatty acid (PUFA) intake data were extracted into a data file. In addition, SD, energy percentage (En\%) with SD, sample size, age, body mass index (BMI), nutritional assessment method and country were extracted. In order to compare the energy and nutrient intake data with NRV, information was extracted per sex and subgroup (i.e. per age category, country, year of data collection). In case of longitudinal studies, baseline data were used, or when baseline data were not provided in the article, the follow-up measurement data were used. Dietary fibre intake data were excluded because the fibre definitions used were not consistently stated in the articles. If no SD was provided, it was calculated based on the SEM. In case En\% was not provided in the article, it was calculated via the daily total energy and gram nutrient intake data, using the Atwater factors [23].

The quality of the included studies and the potential bias on the outcome were assessed based on the Newcastle-Ottawa quality assessment scale [24] and the Cochrane coding manual for cohort studies [25]. Criteria that were applicable to observational studies were selected from these scales and combined to assess the quality. Potential subject selection bias within each study was addressed via (a) assessing whether the study included a predefined study population and (b) stated inclusion and exclusion criteria. Potential out- 
Table 1. Overview of the study quality assessment

\begin{tabular}{|c|c|c|}
\hline Component & Criteria & $\begin{array}{l}\text { Points } \\
\text { awarded }\end{array}$ \\
\hline $\begin{array}{l}1 \text { Predefined study population (e.g. area, } \\
\text { inclusion period) }\end{array}$ & $\begin{array}{l}\text { Information provided } \\
\text { No information provided }\end{array}$ & $\begin{array}{l}1 \\
0\end{array}$ \\
\hline 2 Inclusion and exclusion criteria & $\begin{array}{l}\text { Clearly stated } \\
\text { Not stated }\end{array}$ & $\begin{array}{l}1 \\
0\end{array}$ \\
\hline 4 Selective reporting bias & $\begin{array}{l}\text { Reported data correspond with initial sample size } \\
\text { Reported data do not correspond with initial sample, rational provided } \\
\text { Reported data do not correspond with initial sample, no information } \\
\text { or incomplete rational provided }\end{array}$ & $\begin{array}{l}1 \\
1 \\
0\end{array}$ \\
\hline
\end{tabular}

EURRECA = European micronutrient recommendations aligned; FFQ = food frequency questionnaire.

Summary score: $0-2$ points $=$ low quality, $3-4$ points $=$ moderate quality, 5 points $=$ high quality.

Table 2. Overview of nutritional reference values used for data analysis

\begin{tabular}{|c|c|c|c|c|}
\hline $\begin{array}{l}\text { Nutrient } \\
\text { Energy }\end{array}$ & $\begin{array}{l}\text { Recommendation } \\
\text { WHO/FAO [27] }\end{array}$ & $\begin{array}{l}\text { Year of publication } \\
2001\end{array}$ & EAR & $\begin{array}{l}\text { Men: } 10.3 \mathrm{MJ} / \text { day }(2,450 \mathrm{kcal} / \text { day })^{\ddagger} \\
\text { Women: } 8.4 \mathrm{MJ} / \text { day }(2,000 \mathrm{kcal} / \text { day })^{\ddagger}\end{array}$ \\
\hline Carbohydrate & WHO/FAO [28] & 2007 & AMDR & $55-75$ En\% \\
\hline \multirow[t]{2}{*}{ Protein } & $\mathrm{IOM}[30]^{*}$ & 2006 & AMDR & $10-35 \mathrm{En} \%$ \\
\hline & WHO [29] & 2007 & EAR & $0.66 \mathrm{~g} / \mathrm{kg} \mathrm{bw} / \mathrm{day}$ \\
\hline MUFA & $\mathrm{WHO} / \mathrm{FAO}[26]$ & 2010 & AMDR & 15-20 En\% \\
\hline PUFA & $\mathrm{WHO} / \mathrm{FAO}[26]$ & 2010 & AMDR & $6-11 \mathrm{En} \%$ \\
\hline
\end{tabular}

* IOM used as WHO states the EAR rather than an AMDR for protein; ${ }^{\ddagger}$ Based on a PAL of 1.6 and a bodyweight of $80 \mathrm{~kg}$ for men and $65 \mathrm{~kg}$ for women.

come bias was assessed per study via (c) rating the assessment method and (d) assessing the absence of selective reporting. Criteria and the point assignment are summarised in table 1. Summary scores of $0-2,3-4$, and 5 were rated as low, moderate and high quality, respectively. Nutrient intake data from national food consumption surveys were extracted from the European Nutrition and Health Report [21] and the EFSA 2012 report [22]. The original articles were, however, used to assess study quality, since the reports overall did not contain detailed information on the quality criteria.

\section{Data Analyses}

Analyses were done in IBM SPSS Statistics, version 19 (IBM Company, USA, 2010). Graphics were created using GraphPad Prism version 6 for Windows (GraphPad Software, La Jolla, Calif., USA, 2013).
Pooled means (with SD) were calculated per nutrient and for men and women separately. In order to test the influence of the study quality on the results, the mean nutrient intakes of the 3 study quality subgroups (i.e. high, moderate, low) were compared using a one-way ANOVA analysis. A p value of $<0.05$ was considered a significant difference.

To assess possible inadequacies for energy and nutrient intakes, the pooled mean intake was semi-qualitatively compared with the acceptable macronutrient distribution ranges (AMDR). The WHO NRV were used, as they reflect the recommendations for the global population (table 2) [26-29]. For the protein AMDR, the Institute of Medicine reference value was used instead, as the WHO did not state an AMDR $[29,30]$. For energy, the reference values for older adults aged 60 years and older with a physical activity level (PAL) of 1.6 (corresponding to a light active lifestyle in communi- 


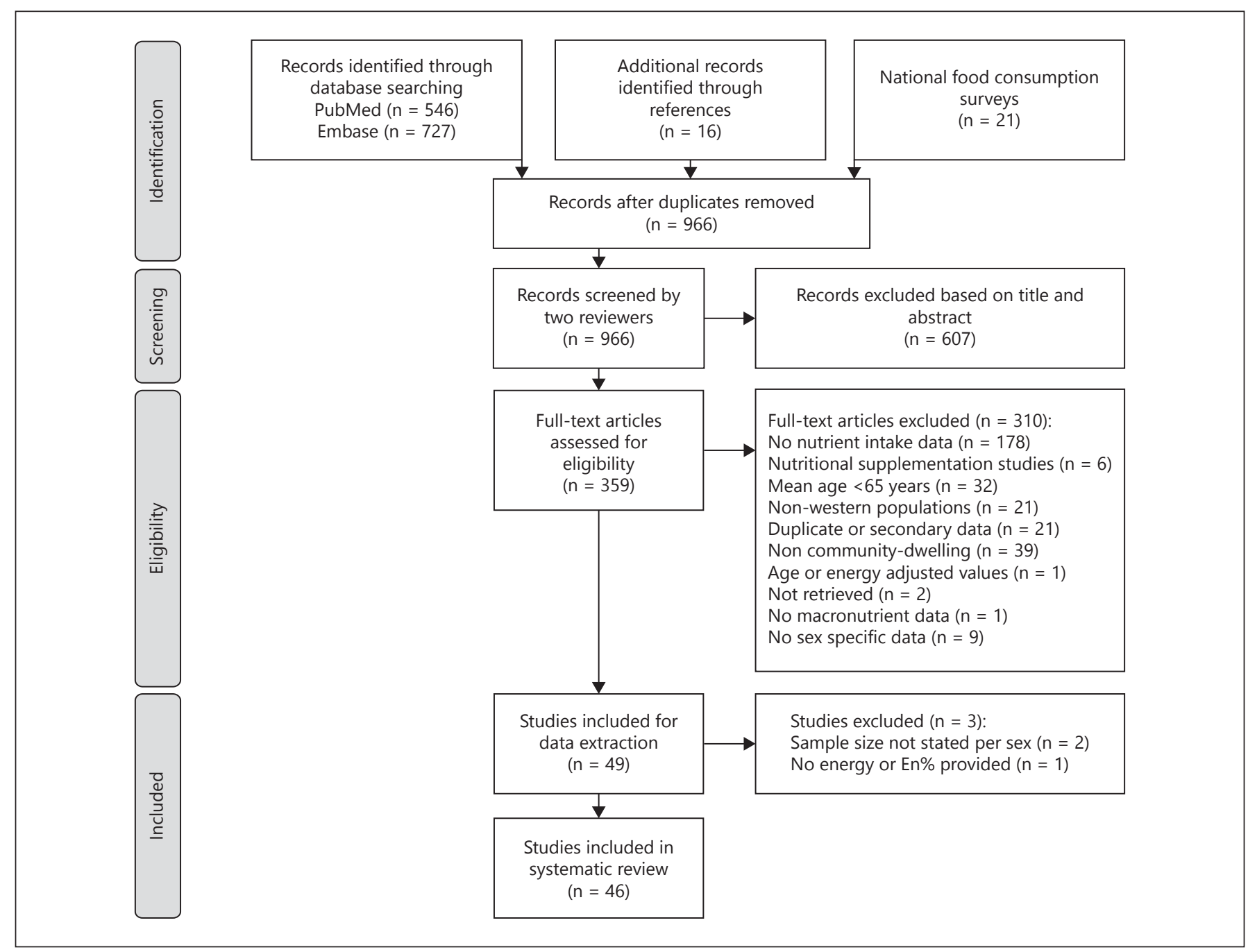

Fig. 1. The PRISMA flowchart indicating the study selection procedure.

ty-dwelling older adults) were used [27, 31, 32]. Since energy reference values are body weight dependent, reference weights of $80 \mathrm{~kg}$ for men and $65 \mathrm{~kg}$ for women were used [33].

In addition, the estimated average requirement (EAR) cutpoint method was used to calculate the prevalence of protein intake inadequacy $[34,35]$. The EAR cut-point was calculated per study. The following calculation was used: $z=(x-\mu) / S D$, with $x$ as the EAR, $\mu$ the mean nutrient intake, and SD the standard deviation of the nutrient intake. The $\mathrm{z}$-score was used to calculate the area below the $\mathrm{z}$-score in a normal distribution (with a mean of 0 and an SD of 1), indicating the percent of the population at risk of inadequacy [34]. The subsequent mean of all studies was calculated to represent the percentage of inadequacy for protein. For the protein EAR the reference value of the WHO, $0.66 \mathrm{~g}$ per kg bodyweight per day (g/kg bw/day), was used [29]. A symmetrical distribution of the protein requirement was assumed [35]. As the protein intake data were provided as gram per day in many studies, the intake was recalculated to $\mathrm{g} / \mathrm{kg}$ bw/day using bodyweights of
80 and $65 \mathrm{~kg}$ for men and women, respectively [33]. As not all studies reported body weight, this predefined bodyweight was instead applied for all studies. The EAR cut-point method is not appropriate for energy, as the intake is dependent on the energy requirement. In addition, this method was not used for carbohydrate and fat intake, as no EARs were available.

\section{Results}

The searches identified 966 records, resulting in the inclusion of 46 studies in the final analyses (fig. 1). The main reasons for exclusion were no nutrient intake data provided and a mean age younger than 65 years. The characteristics of the included studies are presented in table 3. 


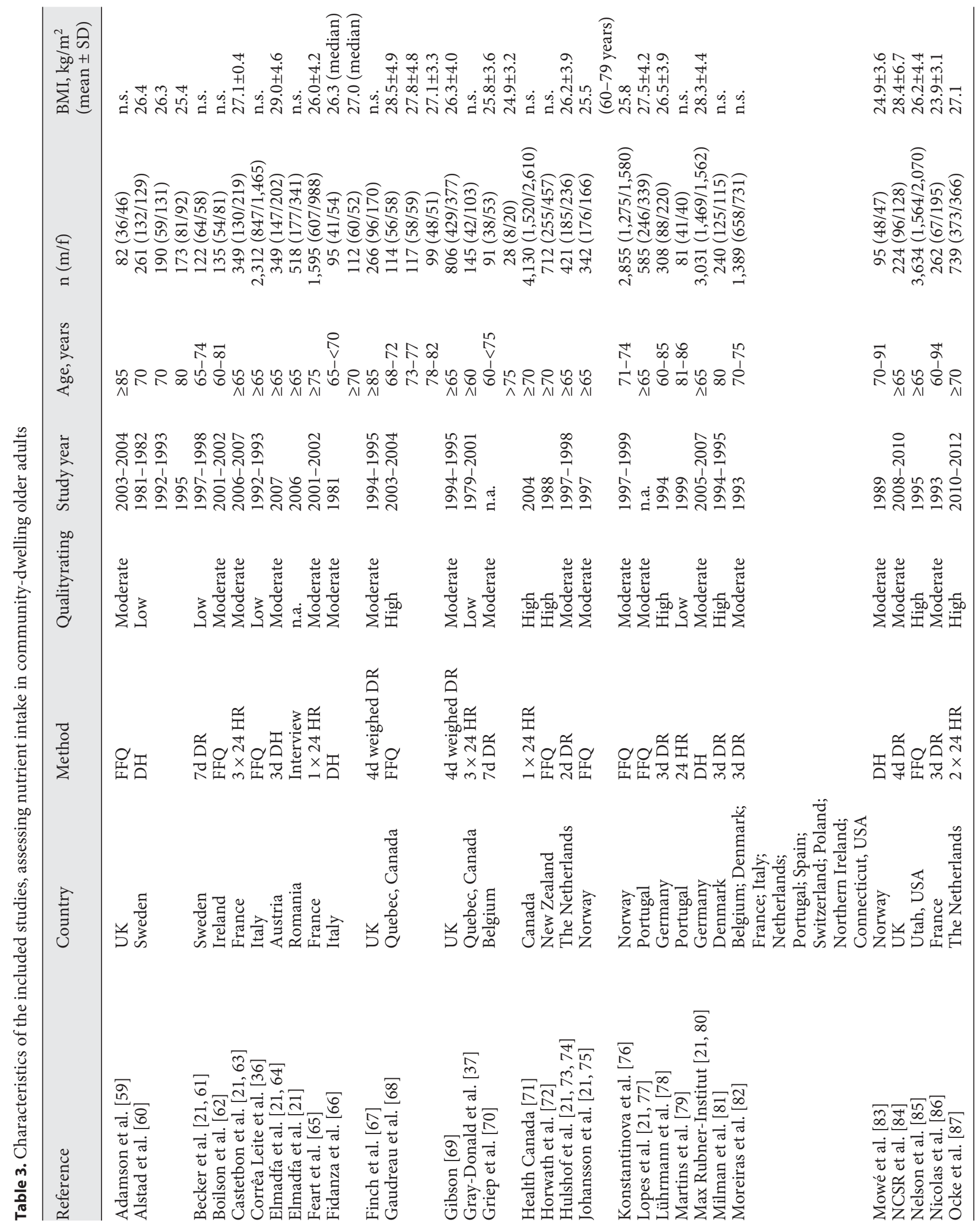




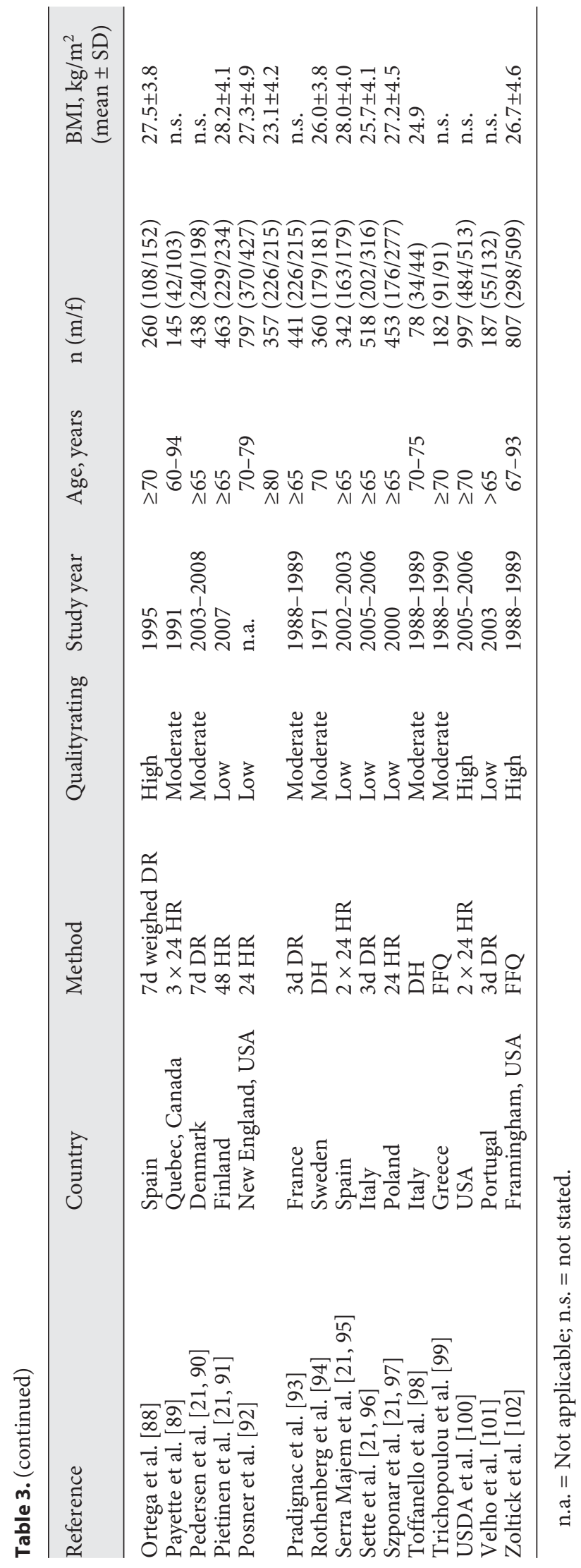

Macronutrient Intakes of Older Adults
Quality assessment of the studies indicated $21 \%$ as low, $55 \%$ as moderate, $21 \%$ as high quality (table 1 ; quality assessment details are provided in online suppl. table S2). The analysis indicated no significant difference in mean nutrient intakes between the quality subgroups (data not shown). As such, all studies were included in the data-analysis (online suppl. tables S3 and S4 with dietary intake data per study). Two studies [36, 37] were excluded from the EAR cut point calculation as the SDs or SEMs were not available in the published data.

The results for the energy and macronutrient intakes are shown in tables 4 and 5 for men and women respectively. The energy intake is presented as a scatterplot in figure 2. The scatterplots for macronutrient intake are presented in figures 3 and 4 for men and women respectively. The mean energy intakes of both men and women were below the EARs of respectively 10.3 and $8.4 \mathrm{MJ} /$ day. Mean carbohydrate intakes of men and women were below the AMDR of $55-75$ En\%, with $96-100 \%$ of the studies with a mean intake below the lower AMDR bound of $55 \mathrm{En} \%$. For both men and women, the protein intakes were within the lower half of the AMDR (10-35 En\%). None of the studies had a mean lower than the lower AMDR bound of 10 En\%. Based on the EAR cut-point method, the mean protein inadequacy was 12 and $10 \%$ in men and women respectively. For both men and women, the mean fat intakes were at the upper end of the AMDR (20-35 En\%). Forty-six per cent of the studies in men and $55 \%$ of the studies in women had mean intakes above the upper AMDR bound. The mean SFA intakes exceeded the upper acceptable range of 10 En\%, with 78 and $80 \%$ of the studies, in men and women respectively, having a mean above 10 En\%. Mean MUFA intake fell below the acceptable range of $15-20$ En\%, with 80 and $88 \%$ of the studies, in men and women respectively, having a mean below the lower AMDR bound. Mean PUFA intakes in men and women were at the lower end of the acceptable range of 6-11 En\%, with 66 and 59\% of the studies having a mean below the lower AMDR bound of 6 En\%.

\section{Discussion}

Our systematic review identified a suboptimal energy and macronutrient distribution in community-dwelling older adults. These results are in line with intake data of healthy adults (aged 31-50 years), indicating En\% of carbohydrate (43-45 En\%), protein (15-16 En\%), fat (34-35 En\%) and SFA (13 En\%), as reported in the latest 
Table 4. Macronutrient intake in community-dwelling older men and the comparison to the NRV

\begin{tabular}{|c|c|c|c|c|c|c|c|c|c|c|}
\hline Nutrient & $\begin{array}{l}\text { Studies, } \\
\mathrm{n}\end{array}$ & $\begin{array}{l}\text { Subgroups*, } \\
\mathrm{n}\end{array}$ & $\begin{array}{l}\text { Subjects, } \\
\mathrm{n}\end{array}$ & Unit & $\begin{array}{l}\text { Mean } \\
\text { intake }\end{array}$ & SD & NRV & $\begin{array}{l}\text { Intake } \\
\text { compared } \\
\text { to NRV }\end{array}$ & $\begin{array}{l}\% \text { of studies } \\
\text { with mean } \\
\text { intakes } \\
\text { below the } \\
\text { lower bound } \\
\text { AMDR }\end{array}$ & $\begin{array}{l}\% \text { of studies } \\
\text { with mean } \\
\text { intakes } \\
\text { above the } \\
\text { upper bound } \\
\text { AMDR }\end{array}$ \\
\hline Energy & 46 & 65 & 14,419 & $\begin{array}{l}\text { MJ/day } \\
\text { (kcal/day) }\end{array}$ & $8.9(2,137)$ & $1.5(350)$ & $10.3(2,450)$ EAR & below $^{\ddagger}$ & n.a. & n.a. \\
\hline Carbohydrates & 36 & 55 & 10,295 & En\% & 46 & 4 & 55-75 AMDR & below & 100 & 0 \\
\hline \multirow[t]{3}{*}{ Protein } & 40 & 57 & 11,974 & g/day & 81 & 13 & & & & \\
\hline & 40 & 57 & 11,974 & En\% & 15 & 2 & 10-35 AMDR & within lower half & 0 & 0 \\
\hline & 40 & 57 & 11,974 & $\mathrm{~g} / \mathrm{kg}$ bw/day & 1.0 & 0.2 & $0.66 \mathrm{EAR}$ & $12 \%$ inadequate $^{\dagger}$ & & \\
\hline \multirow[t]{2}{*}{ MUFA } & 27 & 40 & 8,534 & g/day & 32 & 8 & & & & \\
\hline & 27 & 40 & 8,534 & En\% & 13 & 2 & 15-20 AMDR & below & 80 & 0 \\
\hline \multirow[t]{2}{*}{ PUFA } & 26 & 41 & 8,617 & g/day & 13 & 5 & & & & \\
\hline & 26 & 41 & 8,617 & En\% & 5 & 2 & 6-11 AMDR & at lower end & 66 & 0 \\
\hline
\end{tabular}

n.a. = Not applicable.

* Including subgroups within studies; ${ }^{\ddagger}$ EAR cut-point method cannot be applied as energy intake and requirement are related; ${ }^{\dagger}$ mean $\%$, based on 55 studies, 11,085 subjects.

Dutch National Food Survey [38]. The Dutch survey indicates that excessive SFA intakes increase with age, which may be a concern for the older adult population. Energy intake was however higher in the general Dutch adult population $(11 \mathrm{MJ} /$ day in men and $8 \mathrm{MJ} /$ day in women) [38]. None of the healthy adults had protein intakes below the EAR [38], in contrast to our findings, which indicate that $10-12 \%$ of the older adults had intakes below the EAR.

Comparing our results with those of the NHANES 2003-2004 study [39] (men, mean age 44 years) revealed a similar macronutrient distribution, with a daily intake of $48 \mathrm{En} \%$ for carbohydrates, $33 \mathrm{En} \%$ for fat and $15 \mathrm{En} \%$ for protein [39]. The energy intake in this younger population is, however, also higher (11.7 MJ/day) compared to that observed in our results.

Although the macronutrient En\% are comparable, the higher energy intakes in both the Dutch survey and NHANES study indicate a higher absolute macronutrient intake in healthy adults versus our pooled analysis for older adults.

\section{Energy}

Energy intakes among our pooled population of older adults were below the NRV. Low dietary energy intakes in community-dwelling older adults are often reported [4042]. Unfortunately (risk of) malnutrition was not documented consistently in the included studies, which makes it difficult to arrive at the underlying causes of the low intakes. In addition, body weight could not be retrieved for all studies. We therefore assumed a bodyweight of $80 \mathrm{~kg}$ for men and $65 \mathrm{~kg}$ for women [33], which may have introduced an over- or underestimation of their energy need. Energy underreporting should also be considered, as it is a methodological concern of dietary assessments. Mean BMI ranged from 23 to $29 \mathrm{~kg} / \mathrm{m}^{2}$ (table 3), indicating that these older adults are in general in the normal range or overweight [43]. Those with a higher BMI tend to underreport more frequently, although this seems to be less likely in older adults [44]. Community-dwelling older adults nevertheless are known to underreport their intakes by 10-15\% [45]. Another possible explanation for our observed energy inadequacy could be our choice for the ref- 
Table 5. Macronutrient intake in community-dwelling older women and the comparison to the NRV

\begin{tabular}{|c|c|c|c|c|c|c|c|c|c|c|}
\hline Nutrient & $\begin{array}{l}\text { Studies, } \\
\mathrm{n}\end{array}$ & $\begin{array}{l}\text { Subgroups*, } \\
\mathrm{n}\end{array}$ & $\begin{array}{l}\text { Subjects, } \\
\mathrm{n}\end{array}$ & Unit & $\begin{array}{l}\text { Mean } \\
\text { intake }\end{array}$ & SD & NRV & $\begin{array}{l}\text { Intake } \\
\text { compared } \\
\text { to NRV }\end{array}$ & $\begin{array}{l}\% \text { of studies } \\
\text { with mean } \\
\text { intakes } \\
\text { below the } \\
\text { lower bound } \\
\text { AMDR }\end{array}$ & $\begin{array}{l}\% \text { of studies } \\
\text { with mean } \\
\text { intakes } \\
\text { above the } \\
\text { upper bound } \\
\text { AMDR }\end{array}$ \\
\hline Energy & 46 & 65 & 19,413 & $\begin{array}{l}\text { MJ/day } \\
\text { (kcal/day) }\end{array}$ & $7.3(1,737)$ & $1.2(297)$ & $8.4(2,000)$ EAR & below ${ }^{\ddagger}$ & n.a. & n.a. \\
\hline Carbohydrates & 36 & 55 & 10,295 & En\% & 47 & 4 & 55-75 AMDR & below & 96 & 0 \\
\hline \multirow[t]{3}{*}{ Protein } & 40 & 57 & 16,436 & g/day & 69 & 11 & & & & \\
\hline & 40 & 57 & 16,436 & En\% & 16 & 2 & 10-35 AMDR & within lower half & 0 & 0 \\
\hline & 40 & 57 & 16,436 & $\begin{array}{l}\mathrm{g} / \mathrm{kg} \\
\text { bw/day }\end{array}$ & 1.1 & 0.2 & $0.66 \mathrm{EAR}$ & $10 \%$ inadequate $^{\dagger}$ & & \\
\hline SFA & 31 & 46 & 13,372 & En\% & 13 & 3 & $<10$ upper-AMDR & above & n.a. & 80 \\
\hline \multirow[t]{2}{*}{ MUFA } & 27 & 40 & 11,932 & g/day & 26 & 7 & & & & \\
\hline & 27 & 40 & 11,932 & En $\%$ & 13 & 3 & 15-20 AMDR & below & 88 & 3 \\
\hline \multirow[t]{2}{*}{ PUFA } & 26 & 41 & 12,026 & g/day & 11 & 4 & & & & \\
\hline & 26 & 41 & 12,026 & En\% & 6 & 2 & 6-11 AMDR & at lower end & 59 & 2 \\
\hline
\end{tabular}

n.a. = Not applicable.

* Including subgroups within studies; ${ }^{\ddagger}$ EAR cut-point method cannot be applied as energy intake and requirement are related; ${ }^{\dagger}$ mean $\%$, based on 55 studies, 14,868 subjects.

Fig. 2. Daily energy intake in community-dwelling older men and women, expressed as MJ/day. Data are represented as a scatterplot. Each grey point indicates a study (or subgroup) mean intake, black bars indicate the mean and SD of the pooled analysis. The EARs are represented by grey lines.

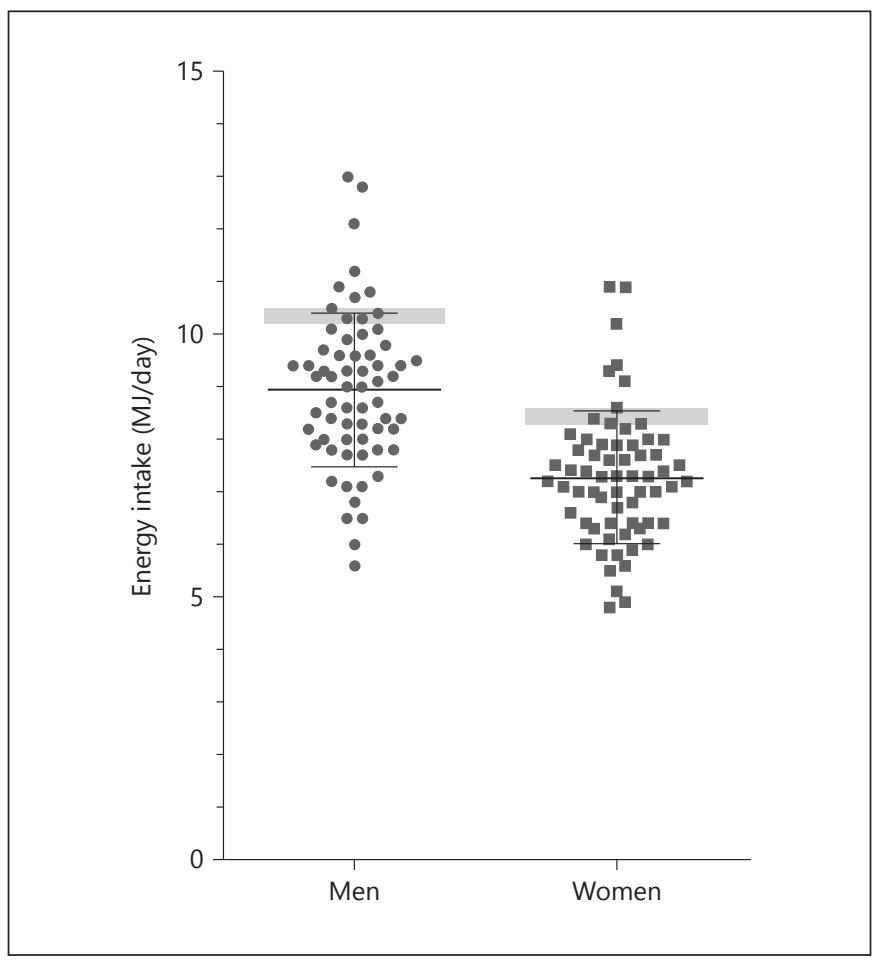

Ann Nutr Metab 2015;66:242-255 
Fig. 3. Daily macronutrient intake in community-dwelling older men, expressed as En\%. Data are represented as a scatterplot. Each grey point indicates a study (or subgroups) mean intake, black bars indicate the mean and SDs of the pooled analysis. The AMDR are represented by grey squares; for SFA the upper-AMDR is indicated.

Fig. 4. Daily macronutrient intake in community-dwelling older women, expressed as En\%. Data are represented as a scatterplot. Each grey point indicates a study (or subgroups) mean intake, black bars indicate the mean and SDs of the pooled analysis. The AMDR are indicated with grey squares; for SFA the upper-AMDR is indicated.
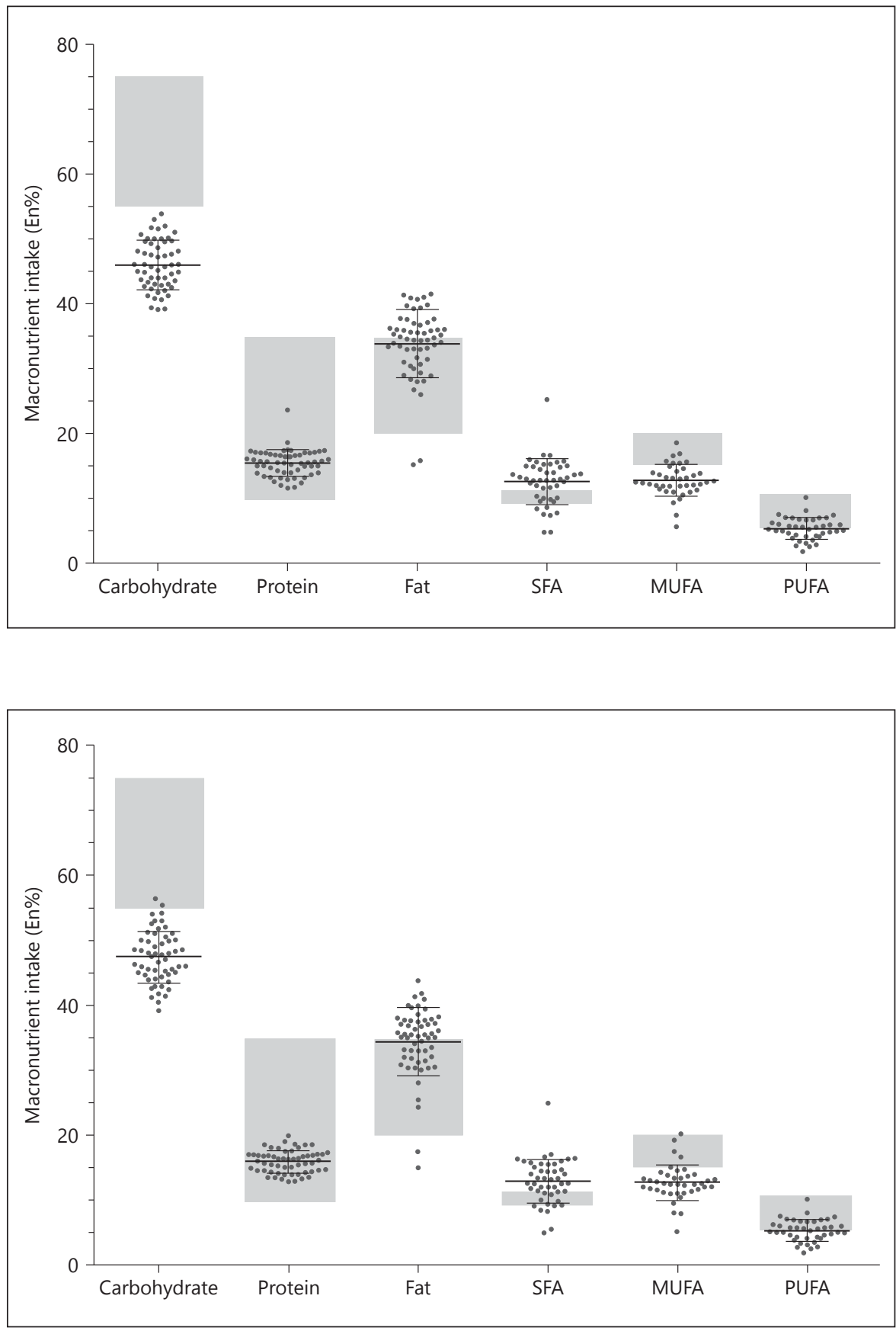

erence PAL value of 1.6. Although this reflects a light active lifestyle, it might have been an overestimation of the level of physical activity and subsequent energy requirement for our pooled population. A recent doubly labelled water study among older adults (mean age of 82), suggested an energy requirement of $9.2 \mathrm{MJ} /$ day for men and $7.6 \mathrm{MJ} /$ day for women [46]. Our observed mean intakes of 9.0 and 7.3 $\mathrm{MJ} /$ day for men and women, respectively, are more in line with these lower reference values and could suggest that our population was less active than initially anticipated. These lower energy references are corresponding with a PAL of 1.45, indicating a sedentary lifestyle [27]. Another point that should be considered are the broad ranges of energy intake observed in this systematic review, which indicate that there is a large variation in intake among older adults. The qualitative method used in this study, com- 
paring the pooled intake with the reference value, however, does not take this into account. Although the mean intake levels indicate a low energy intake, part of the community-dwelling older adults might overconsume energy, depending on their energy need. Based on these considerations, additional information is needed on energy expenditure, bodyweight (changes) and PAL in communitydwelling older adults, to determine the energy requirement and identify a possible energy imbalance.

\section{Macronutrients}

Carbohydrate intake was below the AMDR in the community-dwelling older adults. Based on our data, it is however unclear which type of carbohydrates are consumed; it would be of added value to know the intakes of sugars and dietary fibre. As with energy, the reference value used influences the conclusion on intake inadequacy. When comparing the intake with the AMDR (45-65\%) of the Institute of Medicine, for instance, the mean carbohydrate intake would be at the lower bound rather than below the AMDR.

Protein intake was in the lower half of the AMDR of 10-35 En\%. When applying the cut point method, 10$12 \%$ of the community-dwelling older adults were found to have an inadequate intake compared to the EAR of 0.66 $\mathrm{g} / \mathrm{kg}$ bw/day. These results are in line with a recent finding by Tieland et al. [47], who found that $10 \%$ of community-dwelling older adults did not meet the EAR for protein intake. Recent studies argue that the current recommended daily allowance (RDA) of $0.8 \mathrm{~g} / \mathrm{kg}$ bw/day, corresponding with the EAR of $0.66 \mathrm{~g} / \mathrm{kg}$ bw/day, might not be adequate for the older population $[13,48]$. The RDA is aimed at preventing deficiencies and is based on nitrogen balance rather than achieving an optimal intake to maintain health and function $[13,48]$. The WHO proposes that a protein intake of $0.9-1.1 \mathrm{~g} / \mathrm{kg}$ bw/day is beneficial for healthy older adults [49]. Others argue that the reference value should be increased to $1.0-1.2 \mathrm{~g} / \mathrm{kg}$ bw/ day $[12,50]$ or even to $1.0-1.5 \mathrm{~g} / \mathrm{kg}$ bw/day [51]. The reference value chosen strongly influences the conclusions of inadequacy. As an example, if we consider a protein RDA of $1.0 \mathrm{~g} / \mathrm{kg}$ bw/day, the corresponding EAR (taking into account a coefficient of variation of $10 \%[52,53])$, is $0.83 \mathrm{~g} / \mathrm{kg}$ bw/day. Applying the cut-point method, the percentage of older adults that has a protein inadequacy would increase to $27 \%$ in men and $23 \%$ in women. Another illustration of uncertainty regarding the optimal level of protein intake, also described by Wolfe et al. [54], is that the AMDR reflects a broad range when the En\% provided by protein is converted to $\mathrm{g} / \mathrm{kg}$ bw/day. Based on the energy reference value of $10.3 \mathrm{MJ} /$ day for men and a bodyweight of $80 \mathrm{~kg}$, the AMDR range (10-35\%) would reflect an intake of $61-214 \mathrm{~g}$ protein per day, which equals $0.76-2.68 \mathrm{~g} / \mathrm{kg} \mathrm{bw} /$ day.

Fat intake was at the upper end of the reference value. In addition, the distribution of fatty acid consumption is not optimal, as SFA consumption is above the reference value, while MUFA and PUFA intake values are below or at the lower end of the reference values. In order to understand the high SFA intake, additional information on the consumption of specific food groups would be of added value. Unfortunately, PUFA intake could not be specified for n-3 and n- 6 fatty acids, since nutrient intake data were limited.

\section{Strengths and Limitations}

To our knowledge, this is the first systematic review describing the energy and macronutrient intake in community-dwelling older adults, with pooled data from multiple Western countries. Due to the large pooled sample size, and wide representation of countries, this systematic review provides a more robust conclusion on energy and macronutrient intakes as opposed to individual studies. Applying a systematic approach and evaluating study quality and risk of bias further strengthen the results.

Some limitations of this systematic review need to be addressed. First, although an extensive search was performed, it cannot be ruled out that we have overlooked some studies or that studies are missing due to publication bias. In addition, the restriction to western countries will make it difficult to generalise the results to older adult populations in other countries. Another aspect is that the nutrient intake in the studies was calculated based on the local food composition tables and might have resulted in differences in calculated nutrient content of food items between countries. Differences in methodology (i.e. dietary assessment methods), heterogeneity within and between study populations (such as age, malnutrition, PAL, diseases, country of residence) and year of assessment should be taken into consideration when interpreting the results. Excluding outlier values, such as the study performed in Romania [21], which had high intakes of energy, and SFA, did not alter our results. Cultural and geographical influences on nutrient intake in the older adult population are however interesting to explore. Another point of attention is the broad range of assessment years among the included studies, ranging from 1979 to 2012. Dietary patterns and food compositions might have changed during this period. As an example, during the years 1977-2010, American older adults (aged 55 years 
and older) increased their caloric intake, with SFAs intakes exceeding the NRV [55].

Whether our conclusions are of public health concern, should be studied in more detail. Research is needed to study the effect of nutrient inadequacies on functional and clinical outcome parameters. Low energy intake may be a potential concern for community-dwelling older adults, as it is related to loss of independence: malnutrition is related to falls [56] and weight loss with sarcopenia and institutionalisation $[18,57]$. Lower protein intakes were found to be associated with an increased loss of appendicular muscle mass [11], and adequate protein intake is identified as one of the pillars of sarcopenia management [51]. Additional research in subgroups (such as frail, obese, sarcopenic) would be of added value to identify potential specific nutritional needs and explore the heterogeneity in dietary intake within the communitydwelling older population.

\section{Conclusion}

This systematic review indicates a suboptimal macronutrient distribution and a large variation in nutrient intakes among community-dwelling older adults. Mean energy (8.9 MJ in men and 7.3 MJ in women), carbohydrates
(46-47 En\%) and MUFA (13 En\%) intakes are below the NRV. Mean fat intake (34 En\%) is relatively high and SFA intake (13 En\%) exceeds the upper-AMDR. While protein intake (15-16 En\%) is within the lower range of the AMDR, results based on the EAR cut-point method indicate that $10-12 \%$ of older adults do not meet the current EAR. To interpret the possible energy imbalance, however, additional information is needed on the estimated $\mathrm{PAL}$, energy expenditure and body weight changes.

\section{Acknowledgements}

The authors would like to thank Jaimie Hemsworth for her assistance in analysing the data and reviewing the manuscript, and Radoslava Trifonova for assisting with the database search. Furthermore, the authors would like to thank the National Institute for Public Health and the Environment, for providing additional data from the Dutch national food consumption survey older adults 2010-2012.

The author's contribution is as follows: S.t.B. drafted the manuscript and was assisted with the analysis by Jaimie Hemsworth. S.t.B., D.M.M. and Jaimie Hemsworth performed the study selection. S.V., Y.C.L., J.M.G.A.S., D.M.M., L.C.P.G.M.d.G. were involved in the design, data interpretation and manuscript revisions.

This work was financially supported by Nutricia Research, Nutricia Advanced Medical Nutrition. S.t.B., Jaimie Hemsworth, S.V., Y.C.L. are Nutricia Research employees. D.M.M., J.M.G.A.S. and L.C.P.G.M.d.G. have no conflict of interest to declare.

\section{References}

1 Landi F, Liperoti R, Russo A, Giovannini S, Tosato M, Barillaro C, Capoluongo E, Bernabei R, Onder G: Association of anorexia with sarcopenia in a community-dwelling elderly population: results from the ilSIRENTE study. Eur J Nutr 2013;52:1261-1268.

2 Chapman IM: Endocrinology of anorexia of ageing. Best Pract Res Clin Endocrinol Metab 2004; 18:437-452.

3 Amarantos E, Martinez A, Dwyer J: Nutrition and quality of life in older adults. J Gerontol A Biol Sci Med Sci 2001;56:54-64.

4 Inzitari M, Doets E, Bartali B, Benetou V, Di Bari M, Visser M, Volpato S, Gambassi G, Topinkova E, De Groot L, Salva A; International Association of Gerontology and Geriatrics (IAGG) Task Force for Nutrition in the Elderly: Nutrition in the age-related disablement process. J Nutr Health Aging 2011;15: 599-604.

5 Visvanathan R, Chapman IM: Undernutrition and anorexia in the older person. Gastroenterol Clin North Am 2009;38:393-409.

6 Mir F, Zafar F, Morley JE: Anorexia of aging: can we decrease protein energy undernutrition in the nursing home? J Am Med Dir Assoc 2013;14:77-79.
7 Roberts SB, Rosenberg I: Nutrition and aging: changes in the regulation of energy metabolism with aging. Physiol Rev 2006;86:651667.

8 Brouwer-Brolsma EM, Bischoff-Ferrari HA, Bouillon R, Feskens EJ, Gallagher CJ, Hypponen E, Llewellyn DJ, Stoecklin E, Dierkes J, Kies AK, Kok FJ, Lamberg-Allardt C, Moser U, Pilz S, Saris WH, van Schoor NM, Weber P, Witkamp R, Zittermann A, de Groot LC: Vitamin D: do we get enough? A discussion between vitamin $\mathrm{D}$ experts in order to make a step towards the harmonisation of dietary reference intakes for vitamin $\mathrm{D}$ across $\mathrm{Eu}$ rope. Osteoporos Int 2013;24:1567-1577.

9 Nordic Council of Ministers: Nordic Nutrition Recommendations 2012, Integrating Nutrition and Physical Activity, ed 4. Copenhagen, Nordic Council of Ministers, 2014.

10 Committee to Review Dietary Reference Intakes for Vitamin D and Calcium, Food and Nutrition Board: Dietary Reference Intakes Calcium, Vitamin D. Washington, Institute of Medicine, 2011.

11 Houston DK, Nicklas BJ, Ding J, Harris TB, Tylavsky FA, Newman AB, Lee JS, Sahyoun NR, Visser M, Kritchevsky SB; Health ABC
Study: Dietary protein intake is associated with lean mass change in older, communitydwelling adults: the health, aging, and body composition (health ABC) study. Am J Clin Nutr 2008;87:150-155.

12 Bauer J, Biolo G, Cederholm T, Cesari M, CruzJentoft AJ, Morley JE, Phillips S, Sieber C, Stehle P, Teta D, Visvanathan R, Volpi E, Boirie Y: Evidence-based recommendations for optimal dietary protein intake in older people: a position paper from the PROT-AGE study group. J Am Med Dir Assoc 2013; 14:542-559.

13 Volpi E, Campbell WW, Dwyer JT, Johnson MA, Jensen GL, Morley JE, Wolfe RR: Is the optimal level of protein intake for older adults greater than the recommended dietary allowance? J Gerontol A Biol Sci Med Sci 2013;68: 677-681.

14 Food and Nutrition Board: Dietary Reference Intakes for Energy, Carbohydrate, Fiber, Fat, Fatty Acids, Cholesterol, Protein, and Amino Acids. Washington, Institute of Medicine, 2005.

15 Martone AM, Onder G, Vetrano DL, Ortolani E, Tosato M, Marzetti E, Landi F: Anorexia of aging: a modifiable risk factor for frailty. $\mathrm{Nu}$ trients 2013;5:4126-4133. 
16 Landi F, Russo A, Liperoti R, Tosato M, Barillaro C, Pahor M, Bernabei R, Onder G: Anorexia, physical function, and incident disability among the frail elderly population: results from the ilSIRENTE study. J Am Med Dir Assoc 2010;11:268-274.

17 Ensrud KE, Ewing SK, Stone KL, Cauley JA, Bowman PJ, Cummings SR; Study of Osteoporotic Fractures Research Group: Intentional and unintentional weight loss increase bone loss and hip fracture risk in older women. J Am Geriatr Soc 2003;51:1740-1747.

18 Payette H, Coulombe C, Boutier V, GrayDonald K: Nutrition risk factors for institutionalization in a free-living functionally dependent elderly population. J Clin Epidemiol 2000;53:579-587.

19 de Groot CP, Enzi G, Matthys C, Moreiras O, Roszkowski W, Schroll M: Ten-year changes in anthropometric characteristics of elderly Europeans. J Nutr Health Aging 2002;6:4-8.

20 Moher D, Liberati A, Tetzlaff J, Altman DG; PRISMA Group: Preferred reporting items for systematic reviews and meta-analyses: the PRISMA statement. PLoS Med 2009;6: e1000097.

21 Elmadfa I, Meyer A, Nowak V, Hasenegger V, Putz P, Verstraeten R, Remaut-DeWinter AM, Kolsteren P, Dostálová J, Dlouhý P, Trolle E, Fagt S, Biltoft-Jensen A, Mathiessen J, Velsing Groth M, Kambek L, Gluskova N, Voutilainen S, Erkkilä A, Vernay M, Krems C, Strassburg A, Vasquez-Caicedo AL, Urban C, Naska A, Efstathopoulou E, Oikonomou E, Tsiotas K, Bountziouka V, Benetou V, Trichopoulou A, Zajkás G, Kovács V, Martos E, Heavey P, Kelleher C, Kennedy J, Turrini A, Selga G, Sauka M, Petkeviciene J, Klumbiene J, Holm Totland T, Andersen LF, Halicka E, Rejman K, Kowrygo B, Rodrigues S, Pinhão S, Ferreira LS, Lopes C, Ramos E, Vaz Almeida MD, Vlad M, Simcic $M$, Podgrajsek K, Serra Majem L, Román Viñas B, Ngo J, Ribas Barba L, Becker W, Fransen H, Van Rossum B, Ocké M, Margetts B, Rütten A, Abu-Omar K, Gelius P, Cattaneo A European nutrition and health report 2009. Ann Nutr Metab 2009;55(suppl 2):1-40.

22 EFSA Panel on Dietetic Products Nutrition and Allergies (NDA): Scientific opinion on the tolerable upper intake level of vitamin D. EFSA J 2012;10:45.

23 McNeill G: Energy in food; in Garrow JS James WPT, Ralph A (eds): Human Nutrition and Dietetics. London, Churchill Livingstone, 2000, pp 27-28.

24 Wells GA, Shea B, O'Connell D, Peterson J, Welch V, Losos M, Tugwell P: The NewcastleOttawa Scale (NOS) for assessing the quality of nonrandomised studies in meta-analyses. 2011. http://www.ohri.ca/programs/clinical_ epidemiology/oxford.asp(accessedDecember 2012).

25 Cochrane Center: Form III for the evaluation of a cohort-study (Formulier III, voor het beoordeling van een cohortonderzoek). http:// dcc.cochrane.org/sites/dcc.cochrane.org/ files/uploads/cohort.pdf (accessed November 2012).

26 Food and Agriculture Organization of the Unites Nations: Fats and fatty acids in human nutrition: report of an expert consultation. FAO Food and Nutrition Paper. 2010. http:// foris.fao.org/preview/25553-0ece4cb94ac52f9a25af77ca5cfba7a8c.pdf (accessed April 2014).

27 Food and Agriculture Organization of the Unites Nations, United Nations University, World Health Organization: Human energy requirements: report of a Joint $\mathrm{FAO} / \mathrm{WHO} /$ UNU Expert Consultation. FAO Food and Nutrition Technical Report Series 1. 2001. http://www.fao.org/docrep/007/y5686e/ y5686e00.htm (accessed November 2012).

28 Mann J, Cummings JH, Englyst HN, Key T, Liu S, Riccardi G, Summerbell C, Uauy R, van Dam RM, Venn B, Vorster HH, Wiseman $\mathrm{M}$ : $\mathrm{FAO} / \mathrm{WHO}$ scientific update on carbohydrates in human nutrition: conclusions. Eur J Clin Nutr 2007;61(suppl 1):S132-S137.

29 World Health Organization, Food and Agriculture Organization of the United Nations, United Nations University: Protein and Amino Acid Requirements in Human Nutrition: Report of a Joint FAO/WHO/UNU Expert Consultation. Geneva, World Health Organization, 2007.

30 National Research Council: Dietary reference intakes: the essential guide to nutrient requirements. 2006. http://www.nap.edu/ catalog/11537.html (accessed November 2012).

31 Speakman JR, Westerterp KR: Associations between energy demands, physical activity, and body composition in adult humans between 18 and 96 years of age. Am J Clin Nutr 2010;92:826-834.

32 The Health Council of the Netherlands: Voedingsnormen Energie, Eiwitten, Vetten en Verteerbare Koolhydraten. Den Haag, The Health Council of the Netherlands, 2001.

33 EFSA Panel on Dietetic Products Nutrition and Allergies (NDA): Scientific opinion on dietary reference values for energy. EFSA J 2013;11:3005.

34 Roman Viñas B, Ribas Barba L, Ngo J, Gurinovic M, Novakovic R, Cavelaars A, de Groot LC, van't Veer P, Matthys C, Serra Majem L: Projected prevalence of inadequate nutrient intakes in Europe. Ann Nutr Metab 2011;59: 84-95.

35 National Research Council: Dietary Reference Intakes: Applications in Dietary Assessment. Washington, The National Academies Press, 2000

36 Corrêa Leite ML, Nicolosi A, Cristina S, Hauser WA, Pugliese P, Nappi G: Dietary and nutritional patterns in an elderly rural population in Northern and Southern Italy: (II). Nutritional profiles associated with food behaviours. Eur J Clin Nutr 2003;57:15221529 .
37 Gray-Donald K, Payette H, Boutier V, Page S: Evaluation of the dietary intake of homebound elderly and the feasibility of dietary supplementation. J Am Coll Nutr 1994;13: 277-284.

38 van Rossum CTM, Fransen HP, VerkaikKloosterman J, Buursma-Rethans EJM Ocke MC: Dutch National Food Consumption Survey 2007-2010, Diet of Children and Adults Aged 7 to 69 Years. Report Number 350050006/2011. National Institute for Public Health and the Environment, 2011.

39 Yancy WS Jr, Wang CC, Maciejewski ML: Trends in energy and macronutrient intakes by weight status over four decades. Public Health Nutr 2014;17:256-265.

40 Marshall TA, Stumbo PJ, Warren JJ, Xie XJ: Inadequate nutrient intakes are common and are associated with low diet variety in rural, community-dwelling elderly. J Nutr 2001; 131:2192-2196.

41 Robinson SM, Jameson KA, Batelaan SF, Martin HJ, Syddall HE, Dennison EM, Cooper C, Sayer AA; Hertfordshire Cohort Study Group: Diet and its relationship with grip strength in community-dwelling older men and women: the Hertfordshire cohort study. J Am Geriatr Soc 2008;56:84-90.

42 Sharkey JR, Branch LG, Zohoori N, Giuliani C, Busby-Whitehead J, Haines PS: Inadequate nutrient intakes among homebound elderly and their correlation with individual characteristics and health-related factors. Am J Clin Nutr 2002;76:1435-1445.

43 World Health Organization: BMI classification. 2006. http://apps.who.int/bmi/index.jsp? introPage=intro_3.html (accessed November 2014).

44 Ferrari P, Slimani N, Ciampi A, Trichopoulou A, Naska A, Lauria C, Veglia F, Bueno-deMesquita HB, Ocké MC, Brustad M, Braaten T, José Tormo M, Amiano P, Mattisson I, Johansson G, Welch A, Davey G, Overvad K, Tjønneland A, Clavel-Chapelon F, Thiebaut A, Linseisen J, Boeing H, Hemon B, Riboli E: Evaluation of under- and overreporting of energy intake in the 24-hour diet recalls in the European prospective investigation into cancer and nutrition (EPIC). Public Health Nutr 2002;5:1329-1345.

45 de Vries JH, de Groot LC, van Staveren WA: Dietary assessment in elderly people: experiences gained from studies in the Netherlands. Eur J Clin Nutr 2009;63(suppl 1):S69-S74.

46 Cooper JA, Manini TM, Paton CM, Yamada Y, Everhart JE, Cummings S, Mackey DC, Newman AB, Glynn NW, Tylavsky F, Harris T, Schoeller DA; Health ABC Study: Longitudinal change in energy expenditure and effects on energy requirements of the elderly. Nutr J 2013;12:73.

47 Tieland M, Borgonjen-Van den Berg KJ, van Loon LJ, de Groot LC: Dietary protein intake in community-dwelling, frail, and institutionalized elderly people: scope for improvement. Eur J Nutr 2012;51:173-179. 
48 Wolfe RR: The role of dietary protein in optimizing muscle mass, function and health outcomes in older individuals. Br J Nutr 2012; 108(suppl 2):S88-S93.

49 World Health Organization: Tufts University School of Nutrition and Policy: Keep Fit for Life. Meeting the Nutritional Needs of Older Persons. Geneva, WHO, 2002.

50 Deutz NE, Bauer JM, Barazzoni R, Biolo G, Boirie Y, Bosy-Westphal A, Cederholm T, Cruz-Jentoft A, Krznariç Z, Nair KS, Singer P, Teta D, Tipton K, Calder PC: Protein intake and exercise for optimal muscle function with aging: recommendations from the ESPEN expert group. Clin Nutr 2014;33:929936.

51 Morley JE, Argiles JM, Evans WJ, Bhasin S, Cella D, Deutz NE, Doehner W, Fearon KC, Ferrucci L, Hellerstein MK, Kalantar-Zadeh K, Lochs H, MacDonald N, Mulligan K, Muscaritoli M, Ponikowski P, Posthauer ME, Rossi Fanelli F, Schambelan M, Schols AM, Schuster MW, Anker SD; Society for Sarcopenia, Cachexia, and Wasting Disease: Nutritional recommendations for the management of sarcopenia. J Am Med Dir Assoc 2010;11:391-396.

52 Australian National Health and Medical Research Council, New Zealand Ministry of Health: Nutrient Reference Values for Australia and New Zealand. Including Recommended Dietary Intakes. Canberra, NHMRC, 2006.

53 Evans WJ: What is sarcopenia? J Gerontol A Biol Sci Med Sci 1995;50:5-8.

54 Wolfe RR, Miller SL: The recommended dietary allowance of protein: a misunderstood concept. JAMA 2008;299:2891-2893.

55 Johnston R, Poti JM, Popkin BM: Eating and aging: trends in dietary intake among older Americans from 1977-2010. J Nutr Health Aging 2014;18:234-242.

56 Meijers JM, Halfens RJ, Neyens JC, Luiking YC, Verlaan G, Schols JM: Predicting falls in elderly receiving home care: the role of malnutrition and impaired mobility. J Nutr Health Aging 2012;16:654-658.

57 Volkert D: The role of nutrition in the prevention of sarcopenia. Wien Med Wochenschr 2011;161:409-415.

58 European Micronutrient Recommendations Aligned: Defining data for assessment of intake and status adequacy from open access and grey literature. http://www.eurreca.org/ everyone/8567/7/0/32 (accessed April 2014).

59 Adamson AJ, Collerton J, Davies K, Foster E Jagger C, Stamp E, Mathers JC, Kirkwood T; Newcastle 85+ Study Core Team: Nutrition in advanced age: dietary assessment in the Newcastle 85+ study. Eur J Clin Nutr 2009;63(suppl 1):S6-S18.

60 Alstad T, Österberg T, Rothenberg E, Steen B, Birkhed D: Intake of monosaccharides, sucrose and fibre in the elderly - a cross-sectional and longitudinal study. Scand J Nutr 1999; 43:147-152.

61 Becker W, Pearson M: Riksmaten 1997-1998. Dietary Habits and Nutrient Intake in Swe- den. Uppsala, Livsmedelsverket, National Food Agency, 2002.

62 Boilson A, Staines A, Kelleher CC, Daly L, Shirley I, Shrivastava A, Bailey SW, Alverson PB, Ayling JE, McDermott AP, MacCooey A, Scott JM, Sweeney MR: Unmetabolized folic acid prevalence is widespread in the older Irish population despite the lack of a mandatory fortification program. Am J Clin Nutr 2012;96:613-621.

63 Castetbon K, Vernay M, Malon A, Salanave B, Deschamps V, Roudier C, Oleko A, Szego E, Hercberg S: Dietary intake, physical activity and nutritional status in adults: the French nutrition and health survey (ENNS, 20062007). Br J Nutr 2009;102:733-743.

64 Elmadfa I, Freisling H, Nowak V, Hofstädter D, Hasenegger V, Ferge M, Fröhler M, Fritz K, Meyer AL, Putz P, Rust P, Grossgut R, Mischek D, Kiefer I, Schätzer M, Spanblöchel J, Sturtzel B, Wagner KH, Zilberszac A, Vojir F, Plsek K, et al: Österreichischer Ernährungsbericht 2008. Wien, Bundesministerium für Gesundheit, 2009.

65 Feart C, Alles B, Merle B, Samieri C, Barberger-Gateau P: Adherence to a Mediterranean diet and energy, macro-, and micronutrient intakes in older persons. J Physiol Biochem 2012;68:691-700

66 Fidanza F, Simonetti MS, Mariani Cucchia L, Giulioni Balucca G, Losito G: Nutritional status of the elderly. II. Anthropometry, dietary and biochemical data of old pensioners in $\mathrm{Pe}$ rugia at the fifth year follow-up. Int J Vitam Nutr Res 1984;54:75-90.

67 Finch S, Doyle W, Lowe S, Bates C, Prentice A, Smithers G, Clarke PC: National Diet and Nutrition Survey: People Aged 65 Years and Over. Volume 1: Report of the Diet and Nutrition Survey. London, The Stationery Office, 1998.

68 Gaudreau P, Morais JA, Shatenstein B, GrayDonald K, Khalil A, Dionne I, Ferland G, Fülöp T, Jacques D, Kergoat MJ, Tessier D, Wagner R, Payette H: Nutrition as a determinant of successful aging: description of the Quebec longitudinal study Nuage and results from cross-sectional pilot studies. Rejuvenation Res 2007;10:377-386.

69 Gibson S: Dietary sugars and micronutrient dilution in normal adults aged 65 years and over. Public Health Nutr 2001;4:1235-1244.

70 Griep MI, Verleye G, Franck AH, Collys K, Mets TF, Massart DL: Variation in nutrient intake with dental status, age and odour perception. Eur J Clin Nutr 1996;50:816-825.

71 Health Canada, Statistics Canada: Canadian Community Health Survey, Cycle 2.2, Nutrition (2004). Nutrient Intakes from Food, Provincial, Regional and National Summary Data Tables, Volume 1, 2 and 3. Ottawa, Health Canada, 2009.

72 Horwath CC, Campbell AJ, Busby W: Dietary survey of an elderly New Zealand population. Nutr Res 1992;12:441-453.

73 Hulshof KFAM, van Staveren WA: The Dutch national food consumption survey: design, methods and first results. Food Policy 1991; $16: 257-260$.

74 TNO Voeding: De Voedselconsumptiepeiling (VCP) in Nederland. Deel 1 - basis rapportage derde voedselconsumptiepeiling. 2.3.2: antropometrie en overige persoonskenmerken. 1998. http://www.zuivelengezondheid.nl/tno/Index/Deel-1/b_tabel_01.PDF (accessed November 2014).

75 Johansson L, Solvoll K: Norkost 1997. Landsomfattende kostholdsundersøkelse blant menn og kvinner i alderen 16-79 år. Oslo, Statens råd for ernæring og fysisk aktivitet, 1999.

76 Konstantinova SV, Tell GS, Vollset SE, Ulvik A, Drevon CA, Ueland PM: Dietary patterns, food groups, and nutrients as predictors of plasma choline and betaine in middle-aged and elderly men and women. Am J Clin Nutr 2008; $88: 1663-1669$.

77 Lopes C, Oliveira A, Santos AC, Ramos E, Severo M, Barros H: Consumo Alimentar no Porto. Porto, Department of Hygiene and Epidemiology, 2006.

78 Lührmann PM, Herbert BM, Neuhäuser-Berthold M: Underreporting of energy intake in an elderly German population. Nutrition 2001;17:912-916.

79 Martins I, Dantas A, Guiomar S, Amorim Cruz JA: Vitamin and mineral intakes in elderly. J Nutr Health Aging 2002;6:63-65.

80 Max Rubner-Institut: Nationale Verzehrsstudie II. Ergebnisbericht Teil 1. Die bundesweite Befragung zur Ernährung von Jugendlichen und Erwachsenen. Karlsruhe, Max Rubner Institut, 2008.

81 Milman N, Pedersen AN, Ovesen L, Schroll M: Iron status in 358 apparently healthy 80 -year-old Danish men and women: relation to food composition and dietary and supplemental iron intake. Ann Hematol 2004;83: 423-429.

82 Moreiras O, van Staveren WA, Amorim Cruz JA, Carbajal A, de Henauw S, Grunenberger F, Roszkowski W: Longitudinal changes in the intake of energy and macronutrients of elderly Europeans. SENECA Investigators. Eur J Clin Nutr 1996;50(suppl 2):S67-S76.

83 Mowé M, Bøhmer T, Kindt E: Reduced nutritional status in an elderly population $(>70$ years) is probable before disease and possibly contributes to the development of disease. Am J Clin Nutr 1994;59:317-324.

84 Department of Health: National diet and nutrition survey. Headline results from years 1 and 2 (combined) of the rolling programme (2008/2009-2009/2010). 2011. https://www. gov.uk/government/publications/nationaldiet-and-nutrition-survey-headline-resultsfrom-years-1-and-2-combined-of-the-rolling-programme-2008-9-2009-10 (accessed November 2014)

85 Nelson C, Wengreen HJ, Munger RG, Corcoran CD: Dietary folate, vitamin B-12, vitamin B-6 and incident Alzheimer's disease: the cache country memory, health and aging study. J Nutr Health Aging 2009;13:899-905. 
86 Nicolas AS, Faisant C, Nourhashemi F, Lanzmann-Petithory D, Tome D, Vellas B: Nutrient adequacy of dietary intake in a healthy elderly French population. Eur J Geriatr 2001; 3:140-145.

87 Ocke MC, Buurma-Rethans EJM, de Boer EJ, Wilson-van den Hooven C, Etemad-Ghameslou Z, Drijvers JJMM, van Rossum CTM: Diet of Community-Dwelling Older Adults: Dutch National Food Consumption Survey Older adults 2010-2012. National Institute for Public Health, Sport and the Environment, 2013.

88 Ortega RM, Requejo AM, Andrés P, LópezSobaler AM, Quintas ME, Redondo MR, Navia $B$, Rivas T: Dietary intake and cognitive function in a group of elderly people. Am J Clin Nutr 1997;66:803-809.

89 Payette H, Gray-Donald K, Cyr R, Boutier $\mathrm{V}$ : Predictors of dietary intake in a functionally dependent elderly population in the community. Am J Public Health 1995;85: 677-683.

90 Pedersen AN, Fagt S, Groth M, Christensen T, Biltoft-Jensen A, Matthiessen J, Lyhne Andersen N, Kørup K, Hartkopp H, Hess Ygil K, Hinsch H, Saxholt E, Trolle E: Dietary Habits in Denmark 2003-2008. Main Results. Søborg, DTU Food, National Food Institute, 2010.
91 Pietinen P, Paturi M, Reinivuo H, Tapanainen H, Valsta LM: FINDIET 2007 survey: energy and nutrient intakes. Public Health Nutr 2010;13:920-924.

92 Posner BM, Jette A, Smigelski C, Miller D, Mitchell P: Nutritional risk in New England elders. J Gerontol 1994;49:M123-M132.

93 Pradignac A, Schlienger JL, Velten M, Mejean L: Relationships between macronutrient intake, handicaps, and cognitive impairments in free living elderly people. Aging (Milano) 1995;7:67-74.

94 Rothenberg E, Bosaeus I, Steen B: Food habits and nutrient intake in three 70-year-old freeliving populations in Gothenburg, Sweden. A 22 -year cohort study. Scand J Nutr 1996;40: 104-110.

95 Serra Majem L, Ribas Barba L, Salvador Castell G, Castell Abat C, Román Viñas B, Serra Farró J: Avaluació de L’estat Nutricional de la Població Catalana 2002-2003. Evolució Dels Hàbits Alimentaris i Dels Consum D'aliments i Nutrients a Catalunya (1992-2003). Barcelona, Departament de Salut, Generalitat de Catalunya, 2006

96 Sette S, Le Donne C, Piccinelli R, Arcella D, Turrini A, Leclercq C; INRAN-SCAI 2005-6 Study Group: The third Italian national food consumption survey, INRAN-SCAI 200506 - part 1: nutrient intakes in Italy. Nutr Metab Cardiovasc Dis 2011;21:922-932.
97 Szponar L, Sekula W, Nelson M, Weisell RC: The household food consumption and anthropometric survey in Poland. Public Health Nutr 2001;4:1183-1186.

98 Toffanello ED, Inelmen EM, Minicuci N, Campigotto F, Sergi G, Coin A, Miotto F, Enzi G, Manzato E: Ten-year trends in dietary intake, health status and mortality rates in free-living elderly people. J Nutr Health Aging 2010;14:259-264.

99 Trichopoulou A, Kouris-Blazos A, Wahlqvist ML, Gnardellis C, Lagiou P, Polychronopoulos E, Vassilakou T, Lipworth L, Trichopoulos D: Diet and overall survival in elderly people. BMJ 1995;311:1457-1460.

100 US Department of Agriculture, Agricultural Research Service: Nutrient Intakes from Food: Mean Amounts Consumed per Individual, by Gender and Age, What We Eat in America, NHANES 2009-2010. 2012. www.ars.usda. gov/ba/bhnrc/fsrg. (accessed April 2014).

101 Velho S, Marques-Vidal P, Baptista F, Camilo ME: Dietary intake adequacy and cognitive function in free-living active elderly: a cross-sectional and short-term prospective study. Clin Nutr 2008;27:77-86.

102 Zoltick ES, Sahni S, McLean RR, Quach L, Casey VA, Hannan MT: Dietary protein intake and subsequent falls in older men and women: the Framingham study. J Nutr Health Aging 2011;15:147-152. 